Indonesian Journal of Nutrition and Dietetics Vol. 6, No. 3, 2018: 89-98
Available online at: http://ejournal.almaata.ac.id/index.php/IJND DOI : http://dx.doi.org/10.21927/ijnd.2018.6(3).89-98

\title{
Birth length, maternal height and pesticide exposure were predictors of child stunting in agricultural area
}

\author{
Kusuma Yati Alim¹, Ali Rosidi², Suhartono ${ }^{3}$ \\ ${ }^{1}$ Banjarnegara Health Office, Jalan Selamanik No. 8 Banjarnegara, 53412 \\ ${ }^{2}$ Faculty of Nursing and Health Science Universitas Muhammadiyah Semarang \\ ${ }^{3}$ Departement of Environmental Health, Faculty of Public Health Universitas Diponegoro, \\ *Corresponding author: kusumayatialim@gmail.com
}

\begin{abstract}
ABSTRAK
Latar Belakang: Berdasarkan data PSG Kementrian Kesehatan Tahun 2017 perevalensi stunting di Indonesia 29,6\% (pendek 19,8\% dan sangat pendek 9,8\%) dan prevalensi stunting di Kabupaten Banjarnegara sebesar 30,1\% Prevalensi stunting di Kecamatan Wanayasa mencapai 23,7\%. Rendahnya asupan gizi, faktor genetik dan paparan pestisida merupakan salah satu faktor yang berpengaruh terhadap kejadian stunting. Paparan pestisida sendiri dapat mengakibatkan gangguan metabolisme, pertumbuhan dan perkembangan anak. Kecamatan Wanayasa merupakan salah satu daerah pertanian di Indonesia, terdapat area pertanian kentang dan sayuran dengan intensitas penggunaan pestisida yang tinggi dalam pengolahan lahannya.

Tujuan: Menganalisis faktor risiko stunting pada anak usia 2-5 tahun di daerah pertanian

Metode: Desain penelitian yang digunakan adalah case control dengan jumlah sampel 47 kasus (stunting) dan 47 kontrol (tidak stunting). Pemilihan subjek secara purposive sampling dengan matching umur dan jenis kelamin. Data diperoleh melalui pengukuran tinggi badan , berat badan serta wawancara terstruktur dan untuk asupan gizi dengan menanyakan frekuensi penggunaan bahan makanan responden dalam ukuran rumah tangga dan mengkonversinya dalam ukuran berat (gram). Data dianalisis menggunakan uji chi-square, menghitung Odds Rasio (OR) dan metode regresi logistik.

Hasil: Nilai skor Z TB/U terendah pada kelompok kasus adalah -5.4SD dan tertinggi -2.55SD, umur balita terendah pada kelompok kasus 24 bulan dan pada kelompok kontrol 27 bulan. Sebagian besar pekerjaan ibu baik pada kelompok kasus (51.1\%) maupun pada kelompok kontrol (57.4\%) adalah sebagai petani. Pada analisis bivariat riwayat penyakit kehamilan ibu, tingkat kecukupan gizi (kalsium,zink, protein), riwayat paparan pestisida bumil tidak berhubungan secara bermakna dengan kejadian stunting. Tinggi badan ibu < $150 \mathrm{~cm}(\mathrm{OR}=10.07$; 95\% Cl: 3.57-28.38), panjang badan lahir (OR=11.04; 95\% Cl: 4.19-29.06), dan riwayat paparan pestisida pada anak (OR=4.21;95\% Cl: 1.77-10.04) sebagai faktor risiko stunting. Simpulan: Panjang badan lahir, tinggi badan ibu dan paparan pestisida merupakan faktor risiko stunting pada anak usia 2-5 tahun.
\end{abstract}

Kata Kunci: anak usia 2-5 tahun, daerah pertanian, stunting

\begin{abstract}
Background: According to Nutritional Status Monitoring 2017, stunting prevalence in Indonesia was $29.6 \%$ and stunting prevalence in Banjarnegara District was $30.1 \%$. The prevalence of stunting in Wanayasa Subdistrict was $23.7 \%$. Low nutritional intake, genetic factors and exposure from pesticides are among the factors that influence stunting. Exposure from pesticides can lead to metabolic disorders, growth and development of children. Wanayasa Subdistrict is one of an agricultural area in Indonesia, there is a potato and vegetable farming area with high intensity of pesticide use in the processing of its land.

Objectives: This study aims was to analyze the risk factors for stunting among children age 2-5 years living in an agricultural area.

Methods: The research design was case control measured 47 children as cases and 47 children as controls. Subject selected by purposive sampling with matching age and gender. Data was collected by measurement of height, weight and structured interviews and for nutritional intake with asking the
\end{abstract}


frequency of food intake in household size and converted in weight (gram) method. Data were analyzed using chi-square test, calculating Odds Ratio (OR) and logistic regression method.

Results: The lowest in the case group were -5.4 SD and the highest were -2.55 SD,the lowest age of children was the 24-month in case group and the 27-month in control group. Most of mothers work in case group (51.1\%) and control group (57.4\%) were farmers. In multivariate analysis of mother's height below $150 \mathrm{~cm} \quad(O R=10.07 ; 95 \% \mathrm{Cl}: 3.57-28.38)$, length of birth (OR=11.04; 95\% Cl: 4.19-29.06), and history of pesticide exposure in children (OR=4.21; 95\% Cl: 1.77-10.04) are risk factors for stunting.

Conclusion: Birth length, maternal height and pesticide exposure were risk factor for stunting in children age 2-5 years.

KEYWORDS: children aged 2-5 years, agricultural area, stunting

\section{INTRODUCTION}

Stunting is a form of growth failure due to the accumulation of nutrient inadequacy lasting from pregnancy to 24 months. Stunting reflects chronic malnutrition during the most critical period of growth and development in life. Stunting is defined as the percentage of children aged 0-59 months with height by age $(H / A)$ under -2SD (moderate and severe stunting) and -3SD (severe stunting) of WHO Growth Standard (1).

Many studies have been done with regard to risk factors for stunting in different regions of the developing world. In his study in 137 developing countries, Danaei et al stated that fetal growth disturbances, sanitation (penthouse-free kitchens and pesticide exposure), preterm birth and diarrhea as risk factors for stunting children in developing countries (2). Research conducted by Rachmi et al (2016) showed a strong relationship between stunting and low birth weight, breastfeeding duration, short stature of parent, mother's education level and residence (rural-urban)(3). Environmental factors also affect the occurrence of stunting. Utami et al (2013) states that the history of pesticide exposure was a risk factor for stunting in elementary students in Bulakamba sub-district of Brebes (4). Many other risk factors had been strongly correlated with stunting incidents in children such as preterm birth, short-term infants, micronutrient and macro nutritional adequacy, parenting, family economic status and household food safety (5)(6).

Beside lacking in height stunting also caused other effects in childhood such as development to be inhibited, decreased cognitive function, decreased immune function, and disruption of the combustion system. In adulthood, stunting becomes a risk factor for degenerative diseases, such as diabetes mellitus, coronary heart disease, hypertension, and obesity.

Based on Nutritional Status Monitoring data from the Ministry of Health in 2017 stunting in Indonesia was $29.6 \%$ (stunting $19.8 \%$ and severe stunting $9.8 \%$ ) and stunting prevalence in Banjarnegara District was $30.1 \%$. From the data of Nutritional Status Monitoring conducted by Banjarnegara District Health Office, stunting prevalence in Wanayasa Subdistrict, reach $23.7 \%$ and this stunting incidence mostly found in children aged 2-5 years. In general, farmers in Wanayasa Subdistrict were in cultivating the land which was very familiar with chemical fertilizers and pesticides, $82.5 \%$ of farmers in the use of fertilizers and chemical pesticides tend to be excessive and not in accordance with the dose. Based on the above problems the researcher is interested to examine what risk factors are related to the stunting event in the agricultural area of Wanayasa Subdistrict, Banjarnegara.

\section{MATERIALS AND METHODS}

This research was an observational research used case control design. The research begun with identifying subjects who had stunting (z-score less than $-2 \mathrm{sd}$ ) as case group and subjects who did not have stunting ( $z$-score over -2 sd) as control group. The research was conducted at Puskesmas Wanayasa 2, Wanayasa Subdistrict, Banjarnegara District from November to December 2017. The 
subjects in this study were children aged 2-5 years who met the inclusion criteria and are domiciled in the area of Puskesmas Wanayasa 2, Wanayasa Subdistrict, Banjarnegara with the number of subjects in each case and control group of 47 subjects, so the total number of subjects was 94 subjects. Inclusion criteria in this case group were : 2-5 year olds with stunting, had maternal and child health books or health-related cards, residing in the study area, living with biological parents, willing to be a research sample. Inclusion criteria for control group were : 2-5 year olds without stunting, had maternal and child health books or healthrelated cards, residing in the study area, living with biological parents, willing to be a research sample. Respondents in this research were mothers of toddler selected to be subject. Subject selection used purposive sampling technique, where the selected sample met the requirements in the inclusion criteria.

Data was collected through interviews of respondents by using structured questionnaires and anthropometric measurements on mothers and children using a stadiometer. Questionnaires used based on questionnaires from previous researches that have been validated and standardized. The child's nutritional intake level was measured using semi-quantitative food frequency method for one year period to mother. The child was said to have a short birth length if the birth length was less than $48 \mathrm{~cm}$. Preterm birth was defined if born at gestational age less than 37 weeks. Protein intake was adequate if the intake was $100 \%$ or above of the Nutrition Adequacy Rate. Zinc and calcium intake were adequate if the intake was $77 \%$ or above of the Nutrition Adequacy Rate. Measurement of pesticide exposure was based on interviews about the involvement of children and mothers during pregnancy in agricultural activities. After the data were edited and tabulated, univariate, bivariate and multivariate analyzes were performed. Chi-square test was used for bivariate analysis, with confident interval $(\mathrm{Cl}) 95 \%$, significance level in the study was determined with $p$ value $<0.05$ and risk (OR). Multivariate analysis in this study using logistic regression method. This study has already obtained ethical clearance letter from the Commission Faculty of Health Research Ethics Medicine University of Diponegoro and General Hospital Center of Doctor Kariadi Semarang with number : 68/EC/FK-RSDK/ II/2018.

\section{RESULTS}

The study was conducted on 94 children aged 2-5 years consisting of 47 stunting children and 47 non stunting children obtained from the same population in which children living in agricultural area

Table 1. Characteristic of subjects

\begin{tabular}{lccc}
\hline \multicolumn{1}{c}{ Characteristic } & Cases & Control & p \\
\cline { 2 - 3 } & $(\mathbf{n = 4 7 )}$ & $\mathbf{( n = 4 7 )}$ & $0.97^{\mathrm{a}}$ \\
\hline Age (month), (min, max) & $45(24-60)$ & $46(27-60)$ & \\
Sex, $\mathrm{n}(\%)$ & & & $1.00^{\mathrm{b}}$ \\
Boys & $22(46.81)$ & $22(46.81)$ & \\
Girls & $25(53.19)$ & $25(53.19)$. & \\
Height for age z-score (min, max) & $-2.63(-5.40--2.55)$ & $-1,31(-2.00-0.23)$ & $0.00^{\mathrm{a}}$ \\
Mother Occupation,n (\%) & & & \\
Farmer & $24(51.06)$ & $27(57.45)$ & \\
Trader & $7(14.89)$ & $3(6.38)$ & \\
Others & $4(8.52)$ & $8(17.02)$ & \\
Not working & $12(25.53)$ & $9(19.15)$ & \\
Father Occupation, $\mathrm{n}(\%)$ & $34(72.34)$ & $37(78.72)$ & $0.03^{\mathrm{b}}$ \\
Farmer & $6(12.77)$ & $0(0.00)$ & \\
Trader & $7(14.89)$ & $10(21.28)$ & \\
Others & & \\
\hline
\end{tabular}

Information : a Mann-Whitney test, ${ }^{\mathrm{b}}$ Chi-square test 
working area of Puskesmas Wanayasa 2, Wanayasa Subdistrict, Banjarnegara District by matching age and sex.

The results showed that the characteristics of subjects covering age, sex, and maternal work were not significantly different between case and control groups and there were different meanings on z-score characteristics of height for age and Father's occupation (Table 1). The largest proportion of maternal employment and Father's occupation on case and control groups were farmers. The lowest of height for age in the case group was -5.40 and the highest in the control group was 0.23 .

Based on Table 2 maternal height below 150 $\mathrm{cm}$ was a risk factor for stunting with $\mathrm{OR}=10.07$ $(95 \% \mathrm{Cl}=3.57-28.38)$. Mothers with height less than $150 \mathrm{~cm}$ had 10.07 times higher risk of stunting than mothers with height $150 \mathrm{~cm}$ or above. The result of statistical test showed that there was no significant association between pregnancy disease history and stunting with $p=0.09$. The proportion of subjects with short birth length in case group $(72.3 \%)$ was much greater than in control group (19.1\%). Children with short birth lengths were 11.04 times more likely to have stunting than children of normal birth length. Most of the subjects in both the case (93.6\%) and the control group (97.9\%) had a monthly (not premature) birth history. there were no significant association between protein, zinc and calcium intake with stunting. Most subjects had less calcium intake and adequate levels of protein and zinc in both case and control groups The proportion of mothers with pesticides exposured during pregnancy was slightly greater in case $(61.7 \%)$ than in the control group (53.2\%). There was no significant correlation between pesticide exposured during pregnancy to stunting with $p=0.531$. There was a significant correlation between the history of pesticide exposure

Table 2. Bivariate analysis of independent variable relations with stunting occurrences

\begin{tabular}{|c|c|c|c|c|c|c|c|}
\hline \multirow{2}{*}{ Variables } & & \multicolumn{2}{|c|}{ Case } & \multicolumn{2}{|c|}{ control } & \multirow{2}{*}{ p } & \multirow{2}{*}{$\begin{array}{c}\text { OR } \\
(95 \% \mathrm{Cl}) \\
\end{array}$} \\
\hline & & $\mathbf{n}$ & $\%$ & $\mathbf{n}$ & $\%$ & & \\
\hline \multirow[t]{2}{*}{ Mother's height } & $<150 \mathrm{~cm}$ & 41 & 87.23 & 19 & 40.43 & 0.00 & $\begin{array}{c}10.07 \\
(3.57-28.38)\end{array}$ \\
\hline & $\geq 150 \mathrm{~cm}$ & 6 & 12.77 & 28 & 59.57 & & \\
\hline \multirow[t]{2}{*}{ Pregnancy Disease History } & Yes & 8 & 17.02 & 16 & 34.04 & 0.09 & $\begin{array}{c}0.39 \\
(0.15-1.05)\end{array}$ \\
\hline & No & 39 & 82.98 & 31 & 65.96 & & \\
\hline \multirow[t]{2}{*}{ Birth Length } & Short & 34 & 72.34 & 9 & 19.15 & 0.00 & $\begin{array}{c}11.04 \\
(4.19-29.06)\end{array}$ \\
\hline & Normal & 13 & 27.66 & 38 & 80.85 & & \\
\hline \multirow[t]{2}{*}{ Preterm Birth } & Preterm & 3 & 6.38 & 1 & 2.13 & 0.31 & $\begin{array}{c}3.14 \\
(0.31-31.30)\end{array}$ \\
\hline & No Preterm & 44 & 93.62 & 46 & 97.87 & & \\
\hline \multirow[t]{2}{*}{ Protein Intake } & Adequate & 6 & 12.77 & 6 & 12.77 & 1.00 & $\begin{array}{c}1.00 \\
(0.29-3.36)\end{array}$ \\
\hline & Inadequate & 41 & 87.23 & 41 & 87.23 & & \\
\hline \multirow[t]{2}{*}{ Zinc Intake } & Adequate & 11 & 23.40 & 7 & 14.89 & 0.43 & $\begin{array}{c}1.75 \\
(0.61-4.99)\end{array}$ \\
\hline & Inadequate & 36 & 76.60 & 40 & 85.11 & & \\
\hline \multirow[t]{2}{*}{ Calcium Intake } & Adequate & 46 & 97.87 & 44 & 93.6 & 0.31 & $\begin{array}{c}3.14 \\
(0.31-31.30)\end{array}$ \\
\hline & Inadequate & 1 & 2.13 & 3 & 6.38 & & \\
\hline \multirow[t]{2}{*}{ Pesticide exposure during pregnancy } & Exposed & 29 & 61.70 & 25 & 53.19 & 0.53 & $\begin{array}{c}1.42 \\
(0.62-3.22)\end{array}$ \\
\hline & No exposed & 18 & 38.30 & 22 & 46.81 & & \\
\hline \multirow[t]{2}{*}{ Pesticide exposure in children } & Exposed & 34 & 72.34 & 18 & 38.30 & 0.00 & $\begin{array}{c}4.21 \\
(1.77-10.04)\end{array}$ \\
\hline & No exposed & 13 & 27.66 & 29 & 61.70 & & \\
\hline
\end{tabular}


Tabel 3. Multivariate analysis of stunting risk factors

\begin{tabular}{|c|c|c|c|}
\hline Variable & $\begin{array}{l}\text { Model } 1 \\
\text { OR } \\
(95 \% \mathrm{Cl})\end{array}$ & $\begin{array}{l}\text { Model } 2 \\
\text { OR } \\
(95 \% \mathrm{Cl})\end{array}$ & $\begin{array}{l}\text { Model } 3 \\
\text { OR } \\
(95 \% \mathrm{Cl})\end{array}$ \\
\hline $\begin{array}{l}\text { Pesticide exposure in children } \\
\text { Exposed } \\
\text { No exposed }\end{array}$ & $\begin{array}{c}4.42^{*} \\
(1.52-11.86)\end{array}$ & $\begin{array}{c}2.98^{*} \\
(1.11-7.84)\end{array}$ & $\begin{array}{c}3.02^{*} \\
(1.01-9.03)\end{array}$ \\
\hline $\begin{array}{l}\text { Birth length } \\
\text { Short } \\
\text { Normal }\end{array}$ & $\begin{array}{c}11.08^{*} \\
(3.96-31.08)\end{array}$ & & $\begin{array}{c}8.91^{*} \\
(2.97-26.75)\end{array}$ \\
\hline $\begin{array}{l}\text { Mother's Height } \\
\quad<150 \mathrm{~cm} \\
\quad \geq 150 \mathrm{~cm}\end{array}$ & & $\begin{array}{c}8.16^{\star} \\
(2.82-23.67)\end{array}$ & $\begin{array}{c}5.73^{*} \\
(1.79-18.34)\end{array}$ \\
\hline $\mathrm{R}^{2}(\%)$ & 42.90 & 35.10 & 51.60 \\
\hline$n$ & 94 & 94 & 94 \\
\hline
\end{tabular}

*Significant $(p<0.05)$

in children to stunting. Children with pesticide exposured had 4.2 times higher risk of stunting than unexposed children.

The results of analysis on model 1 showed a significant association between pesticide exposure at children and short birth length with the incidence of stunting (OR=4.42;95\% Cl: $1.52-11.86$, OR=11.08; $95 \% \mathrm{Cl}: 3.96-31.08) . \mathrm{R}^{2}(\%)$ value is $42,90 \%$ so that it can be interpreted that both pesticide exposure at children and short birth length can predict stunting at children aged 2-5 years by $42.90 \%$. Analysis on model 2 showed a significant association between pesticide exposure and mother's height with stunting $(\mathrm{OR}=2,98$; $95 \% \mathrm{Cl}: 1.11-7.84, \mathrm{OR}=8.16 ; 95 \% \mathrm{Cl}: 2.82-23.67)$. $\mathrm{R}^{2}(\%)$ value was $35,10 \%$ so that it could be interpreted that together pesticide exposure at children and mother's height below $150 \mathrm{~cm}$ could predict stunting by $35.10 \%$, and $64.90 \%$ was caused by other factors. Based on results of the analysis in table 2 the selected model was model 3 because it has considered all variables that were significant for stunting.

Multivariate test results in model 3 showed that the history of pesticide exposure, the length of birth and the height of mother as stunting risk factor in children in Wanayasa Subdistrict, Banjarnegara. The strength of the relationship value can be seen from the OR value. The greatest strength of the relationship is the length of the child's birth weight
$(\mathrm{OR}=8.91)$ in which children with short birth lengths were 8.9 times more likely to have stunting than children of normal birth length, and the strength of the smallest relationship is the history of pesticide exposure in children $(\mathrm{OR}=3.02)$, in which children with pesticides exposure had 3.02 times higher risk of stunting than unexposed children. Maternal height is an indicator reflecting both genetic and environmental factors on child's growth (7).

\section{DISCUSSION}

The short mother is one of the factors associated with the stunting event (8) One or both parents with short stature due to pathological conditions (such as growth hormone deficiency) and having a gene in chromosomes that carry short traits will increase the chances of children inheriting the gene and growing into stunting. However, if the short stature of the parents due to the influence of external factors such as illness and lack of nutrient intake early on, the possibility of the child can grow with normal height as long as the nutritional intake is met and not exposed to other risk factors (9),(10).

The mean maternal height in the case group was $147.48 \mathrm{~cm}$ and in the control group 151.34 $\mathrm{cm}$. The proportion of subjects with mother height below $150 \mathrm{~cm}$ in the case group $(87.2 \%)$ was much greater than in the control group (40.4\%). Mothers with height below $150 \mathrm{~cm}$ had a higher risk to rome 
stunted children than mothers with height $150 \mathrm{~cm}$ or above (OR=5.73; 95\% Cl: 1.79-18.34) (Table 3). This is in line with research in Sumatra that shows the relationship between maternal height with stunting events. A short mother's height is more at risk of having a stunting child (7).

Most of the subjects in both the case $(83 \%)$ and the control group (66\%) had no history of the disease during pregnancy. The history of diseases during pregnancy of the mother that often occurred in case and control group in this study were anemia $(21.3 \%)$, hyperemesis $(3.2 \%)$ and hypertension $(1.1 \%)$ There was no significant correlation between history of pregnancy disease mother with stunting in children aged 2-5 years. This is possible because the history of the disease during maternal pregnancy is more influential on the birth process and outcome of the baby being born (11), while the growth of infants after birth is influenced by many other factors such as environmental factors, nutrient intake, or infectious diseases (12). In addition, this study also did not see the time of the disease (early trimester, second trimester or late trimester), mothers who had health problems during pregnancy have a higher risk to rome stunting children (8).

There was a significant relationship between the length of the birth and the occurrence of stunting in children aged 2-5 years, and the proportion of subjects in the case group (72.3\%) was significantly greater than in the control group (19.1\%) with $\mathrm{p}=0.000$ and as a stunting risk factor with $\mathrm{OR}=8.91$ (95\% Cl: $2.97-26.75)$ (Table 3). The result is in line with previous studies where birth weight was significantly linked with stunting (13),(14). The risk of stunting in infants is affected by the birth status, especially the length and weight at birth (15). Body size at birth can predict the growth of the fetus, the length of the newborn is a strong predictor of body stature as a teenager. Short children at birth and not catch-up will have short stature as a teenager (16),(8).

There was no significant relationship between preterm birth and stunting. The results of this study differ from the research in Kendal District which concluded that children born prematurely have a risk of 11.5 times to experience the incidence of stunting compared to children who were born enough months (17). In preterm infants who have growth faltering if given adequate nutritional support, it will achieve catch up growth (18). Catch up growth in preterm infants usually occurs during the first 2-3 years, maximum at the age of 36-40 weeks after conception, little occurs after the age of 3 years. Usually first seen in the circumference of the baby's head, followed by weight and body length (19).

Most of subjects in both case $(97.9 \%)$ and control group (93.6\%) had less calcium adequacy. The average calcium adequacy rate in the case group was $41.49 \%$ and in the control group of $39.15 \%$. However was no significant relationship between calcium adequacy and stunting. Calcium absorption is influenced by many factors including the amount of calcium in the diet, calcium supply (can be bound by phytate and oxalic acid), age and other nutrients (20). The highest intake of calcium in the subject is obtained from milk, biscuits, eggs, and fish. At least the amount of food sources of calcium consumed by the subject allows the calcium intake of the subject is still lacking. The consumption behavior of drinking milk was still low, the average subject consumes milk only 1-2 times a week, fish 2-3 times a week and which was often consumed was egg.

The result of the study stated that the variable of protein and stunting in children aged 2 - 5 years did not have significant. There was no difference in proportion in the category of protein adequacy rate between case and control groups. Most subjects in both case and control groups had sufficient protein adequacy. The mean protein adequacy level in the case group was $161.01 \%$ and in the control group of $144.53 \%$. The level of protein adequacy in the case group was higher than the control group, it is possible to recall bias during the interview. The protein intake in the subject comes from animal protein (eggs of chicken meat, salted fish, fresh fish) and vegetable protein (tofu and tempeh). The high level of protein adequacy in the subject is possible from the high frequency of consumption of tempeh, tofu and eggs. As many as $56.4 \%$ of subjects consumed tempeh and $57.4 \%$ of subjects consumed tofu and $53.2 \%$ of subjects consumed 
eggs every day. The high intake of food sources of protein allows the level of sufficiency of the subject protein beyond the nutritional adequacy rate. The recommended limit for protein consumption is twice the nutritional adequacy rate. This study is in line with Rahmaniah's (2014) and Khasanah's (2016) were stated there was no significant relationship between protein intake and stunting (21),(22). Another stated that stunting and child's dietary divensity were strongly related(23)

The main function of protein is for growth, but when the body lacks energy substances, the function of proteins to produce energy or to form glucose will take precedence. When the glucose or fatty acids in the body are limited, the cells are forced to use proteins to form glucose and energy. Protein breakdown to meet energy and glucose needs will ultimately lead to muscle weakening.

The occurrence of nutrient absorption disorders can also be caused by poor sanitation (pathogenic bacterial infections, parasites-viruses), dietary exposure (antigen and preservatives in foods, microbial metabolites), mycotoxins and exposure to toxic substances in the environment (pesticides, heavy metals), which referred to as environmental enteric dysfunction (EED). High intake of nutrients, energy and protein will not provide enough benefits to grow flowers in the event of EED (24),(25).

There was no significant correlation between zinc intake and stunting in children in Wanayasa Subdistrict, Banjarnegara District. This is in contrast to research conducted by Hidayati in Surakarta, revealed that zinc deficiency has 2.67 times greater risk of stunting in children (26). Most of the subjects had a sufficiently good zinc adequacy rate in the case group $(76.6 \%)$ as well as in the control group $(85.1 \%)$. The average zinc intake in the case group was $3.67 \mathrm{mg}$ and in the control group $3.81 \mathrm{mg}$ and the lowest zinc intake was $1.7 \mathrm{mg}$ (in the case group).

The highest intake of zinc in the subject was obtained from animal food sources such as eggs, chicken meat, fresh fish and salted fish and from vegetable sources such as tofu, tempeh and green leafy vegetables. Although the level of adequacy of zinc is enough but there are many factors that affect the absorption of zinc, among others, fiber, phytic acid and oxalic acid that can bind zinc and inhibit its absorption. The amount of albumin in plasma as the main determinant of absorption of zinc and albumin as the main transport zinc. The absorption of zinc will decrease when the value of albumin in the blood decreases, for example when the child is malnourished. Some zincs use a transferin transport device that is also an iron transport vehicle. Zinc absorption will be inhibited when the amount of non-heme iron exceeds zinc. When iron and zinc are given together with a ratio of more than 2:1, the transferrin available for zinc decreases and the absorption of zinc decreases, so even if the amount of zinc is high but which is absorbed may be less (27)

Growth disorders can also be caused by environmental factors, one of which comes from harmful chemicals in the environment that can interfere with hormonal function (Endocrine Disrupting Chemicals/EDCs). Pesticides are one of the most commonly used chemicals in agricultural activities and are classified as EDCs (24),(25). The result of statistical test showed that there was no significant correlation between the history of exposure of mother pesticide during pregnancy to stunting event in children. Exposure of pregnant women to pesticides is related to the work of pregnant women themselves as farmers. The pathogenesis of pesticide poisoning in pregnant women starts from the entry of pesticides through the skin (contact), digestive tract (oral) and respiratory system (inhalation). Pesticides then enter into the mother's blood circulation, placenta, and enter the fetus, causing disruption of fetal growth (28).

The type of maternal activity in agriculture, the length of exposure, the frequency of pesticide exposure and the use of personal protective equipment is related to the level of exposure of pesticides to the mother during pregnancy. Based on the results of interviews with the subject, it is known that during pregnancy the mothers reduce their activities involved in agricultural activities by reducing the frequency of work in the fields. The involvement of mothers in agricultural activities during pregnancy includes planting activities, removing grass from plants (matun), looking for 
pests, watering and harvesting crops (harvesting), mothers not involved in spraying activities due to spraying activities done more by men, men. While working on the ground most subjects have used personal protective equipment (PPE) such as boots, long-sleeved shirts, gloves, hats), but never wear a mask for not engaging in spraying activities. Use of PPE allows reducing the risk of exposure to pesticides.

There was a significant correlation between the history of pesticide exposure in children to stunting in Subdistrict Wanayasa, Banjarnegara, and the proportion of subjects in the case group $(72.3 \%)$ was significantly greater than in the control group (38.3\%). Insecticides, fungicides and herbicides are common pesticides used by farmers in Wanayasa District. The occurrence of pesticide exposure in children is possible because children always follow the mother while working in the field on the grounds no one keeps at home. Children follow the mother to the farm area when the mother planting, remove the grass from the plants, look for pests, watering and harvesting crops (harvest), but children are not involved in spraying activities. Children are also accustomed to play around the agricultural area Unavailability of special room to store pesticide so that put in open room in house also possible happened exposure of pesticide in child.

Growth disorders that occur due to exposure to pesticides can be through several mechanisms, among others through the disturbance of the hormone system that plays a role in the growth process. Some types of pesticides are widely used in agriculture classified as EDCs (Endocrine Disrupting Compounds) is a chemical compound in the environment that interfere with biosynthesis, metabolism or natural hormonal reactions that result in deviation homeostasis, reproduction and growth process (4).

The theory of the mechanism of the occurrence of disorders of thyroid function due to exposure to pesticides can be through several mechanisms that interfere with thyroid stimulating hormone (TSH) receptor in the thyroid gland, the similarity of the chemical structure of pesticides with thyroid hormone (29), decrease the action of enzyme D1 (deiodinase type 1) (30), stimulate the work of D3 enzyme (deiodinase type 3)(31). Pesticides have the same chemical structure as thyroid hormone, when pesticides enter the body, TSH receptors capture the pesticide and not the thyroid hormone causing disruption of metabolic processes in the body. In deiodinase type 1 hormone T4 (thyroxine) is converted into an active T3 hormone (triiodothyronin) that regulates metabolism, growth, development and activity of the nervous system (neurotransmitter). In deiodinase type 3 hormone T4 (thyroxine) and T3 (triiodothyronin) is converted to rT3 (reverse triiodothyronin) by activating the action of D3 enzyme. Thyroid hormone and IGF-1 are highly needed hormones in a child's growth process and organophosphorus pesticide exposure may disrupt the function of IGF-1(25).

\section{CONCLUSIONS AND RECOMMENDATIONS}

Birth length, maternal height and history of pesticide exposure in children as risk factor for stunting in children aged 2-5 years in Wanayasa Subdistrict, Banjarnegara District. There was no significant association between maternal pregnancy disease, preterm birth, calcium adequacy, protein adequacy, zinc adequacy and pesticide exposure during pregnancy with stunting events.

Health workers should be able to provide intensive counseling to all women of childbearing age to maintain nutritional intake in the pre-adolescent, adolescence to pregnancy to prevent short-term birth in infants, intensive counseling to the public about the dangers of exposure to pesticides. The need to improve daily practice in the use of pesticides, pesticide storage and use of personal protective equipment to prevent exposure for pesticides. Provide balanced nutrition intake by empowering and developing local menus to meet the nutritional intake of toddlers and achieve optimal growth.

\section{REFERENCES}

1. UNICEF. Stunting [Internet]. 2017 [cited 2017 Aug 9]. Available from: http://unicef.in/ Whatwedo/10/Stunting

2. Danaei G, Andrews KG, Sudfeld CR, Fink G, McCoy DC, Peet E et al. Risk Factors 
for Childhood Stunting in 137 Developing Countries: A Comparative Risk Assessment Analysis at Global, Regional, and Country Levels. PLoS Med. 2016;13(11):1-18.

3. Rachmi CN, Agho KE, Li M, Baur LA. Stunting , Underweight and Overweight in Children Aged 2. $0-4.9$ Years in Indonesia: Prevalence Trends and Associated Risk Factors. PLoS One. 2016;11(5):1-17.

4. Utami RP, Suhartono, Nurjazuli, Kartini A, Rasipin. Faktor Lingkungan dan Perilaku yang Berhubungan dengan Kejadian Stunting pada Siswa SD di Wilayah Pertanian (Penelitian di Kecamatan Bulakamba Kabupaten Brebes) Environmental and Behaviour Factors Associated to The Incidence of Stunting In Elementary. J Kesehat Lingkung Indones. 2013;12(2):127-31.

5. Paudel R, Pradhan B, Rr W, Dp P, Sr O. Risk Factors for Stunting Among Children : A Community Based Case Control Study in Nepal. Kathmandu Univ Med J. 2011;10(39):18-24.

6. Victora CG, Villar J, Barros FC, Ismail LC, Chumlea C, Papageorghiou AT et al. Anthropometric Characterization of Impaired Fetal Growth Risk Factors for and Prognosis of Newborns With Stunting or Wasting. JAMA Pediatr. 2015;169(7):1-10.

7. Paramashanti BA, Hadi $\mathrm{H}$, Gunawan IMA. Pemberian ASI eksklusif tidak berhubungan dengan stunting pada anak usia $6-23$ bulan di Indonesia. J Gizi dan Diet Indones. 2015;3(3):162-74.

8. Kusharisupeni. Peran status kelahiran terhadap stunting pada bayi : sebuah studi prospektif. J Kedokt Trisakti. 2002;23(3):73-80.

9. Amigo H, Buston P RM. Is There Are Relationship Between Parent's Short Height and Their Children's? Social Interclass Epidemiologic Study. Rev Med Chil. 1997;125(8).

10. Candra A, Puruhita N, Susanto J. Risk Factors of Stunting among 1-2 Years Old Children in Semarang City. Media Med Indones. 2011;45(Nomor 3):206-12.

11. Medhin G, Hanlon C, Dewey M, Alem A, Tesfaye F, Worku B et al. Prevalence and Predictors of Undernutrition Among Infants Aged Six and Twelve Months in Butajira Ethiopia : The P-Mamie Birth Cohort. BMC Public Health. 2010;10(27).

12. UNICEF. Improving Child Nutrition The achievable imperative for global progress [Internet]. New York, UNICEF. 2013 [cited 2017 Aug 7]. Available from: https://www.unicef.org/ publications/index_68661.html

13. Paratmanitya Y, Hati FS. Gambaran status gizi anak 12-24 bulan di Puskesmas Mergangsan Kota Yogyakarta tahun 2015 : tinjauan riwayat pemberian ASI eksklusif dan kejadian penyakit infeksi. 2015;3(3):149-54.

14. Supriyanto $Y$, Paramashanti BA, Astiti D. Berat badan lahir rendah berhubungan dengan kejadian stuntingpada anak usia 6-23 bulan. J Gizi dan Diet Indones (Indonesian J Nutr Diet [Internet]. 2017;5(1):23-30. Available from: http://ejournal.almaata.ac.id/index.php/IJND/ article/view/442/430

15. Ricci JA BJ. Risk Factors for Wasting and Stunting Among Children in Metro Cebu Philippines. Am J Clin Nutr. 1996;63:966=977.

16. Sterling R, Miranda JJ, Gilman RH, Cabrera L, Sterling CR, Bern C et al. Early Anthropometric Indices Predict Short Stature and Overweight Status in a Cohort of Peruvians in Early Adolescence. Am J Phys Anthropol. 2012;000(March):1-11.

17. Meilyasari F. Faktor Risiko Kejadian Stunting Pada Balita Usia 12 Bulan di Desa Purwokerto Kecamatan Patebon, Kabupaten Kendal. Semarang: Universitas Diponegoro; 2013.

18. Adel El, Ibrahim B, Salah MM AM. Risk Factors for Stunting Among Under-Fives in Libya. Public Health Nutr. 2004;12(8).

19. Trachtenbarg DE, Golemon TB. Care of the Premature Infant : Part I. Monitoring Growth and Development. Am Fam Physician [Internet]. 1998;57(9):2123-30. Available from: https:// www.aafp.org/afp/1998/0501/p2123.html

20. PERSAGI;AIPGI. IImu Gizi Teori dan Aplikasi. Hardinsyah, Supariasa, editors. Jakarta: Penerbit Buku Kedokteran EGC; 2017.

21. Rahmaniah, Huriyati E, Irwanti W. Riwayat asupan energi dan protein yang kurang bukan 
faktor risiko stunting pada anak usia 6-23 bulan. J Gizi dan Diet Indones. 2014;2(3):150-8.

22. Khasanah DP, Hadi H, Paramashanti BA. Waktu pemberian makanan pendamping ASI (MPASI) berhubungan dengan kejadian stunting anak usia 6-23 bulan di Kecamatan Sedayu. J Gizi dan Diet Indones (Indonesian J Nutr Diet. 2016;4(2):105-11.

23. Paramashanti BA, Paratmanitya Y, Marsiswati. Individual dietary diversity is strongly associated with stunting in infants and young children. J Gizi Klin Indones. 2017;14(1):19-26.

24. Breton J, Massart $S$, Vandamme $P$, Brandt E De, Pot $B$, Foligné $B$. Ecotoxicology inside the gut : impact of heavy metals on the mouse microbiome. BioMed Cent Pharmacol Toxicol. 2013;14(62):1-11.

25. Kartini A. Riwayat Paparan Pestisida sebagai Faktor Risiko Kejadian Stunting pada Anak Sekolah Dasar di Daerah Pertanian (Disertasi). Semarang: Universitas Diponegoro; 2017.

26. Hidayati, Hadi H, Kumara A. Kekurangan Energi dan Zat Gizi Merupakan Faktor Risiko Kejadian
Stunted PadaAnak Usia 1-3 Tahun yang Tinggal di Wilayah Kumuh Perkotaan Surakarta. J Kesehat ISSN 1979-7621. 2010;3(1):89-104.

27. Almatsier S. Prinsip Dasar Ilmu Gizi. Jakarta: PT Gramedia Pustaka Utama; 2005.

28. Sari NK. Hubungan Riwayat Pajanan Pestisida pada Ibu Hamil dengan Kejadian Berat Badan Lahir Rendah (BBLR) di Wilayah Kerja Puskesmas Wanasari Kabupaten Brebes. J Kesehat Masy. 2013;2(2):1-11.

29. Boas M, Feldt-rasmussen U, Skakkebæk NE, Main KM. Environmental chemicals and thyroid function. Eur J Endocrinol. 2006;154:599-611.

30. Wade MG, Parent S, Finnson KW, Foster W, Younglai E, McMohan A et al. Thyroid Toxicity Due to Subchronic Exposure to a Complex Mixture of 16 Organochlorines, Lead, and Cadmium. Toxicol Sci. 2002;67:207-18.

31. Gereben ZS, Berry MJ, Bianco AC, Salvatore D, Larsen PR. Biochemistry, Cellular and Molecular Biology, and Physiological Roles of the lodothyronine. Endocr Rev. 2015;23(1):38-89. 